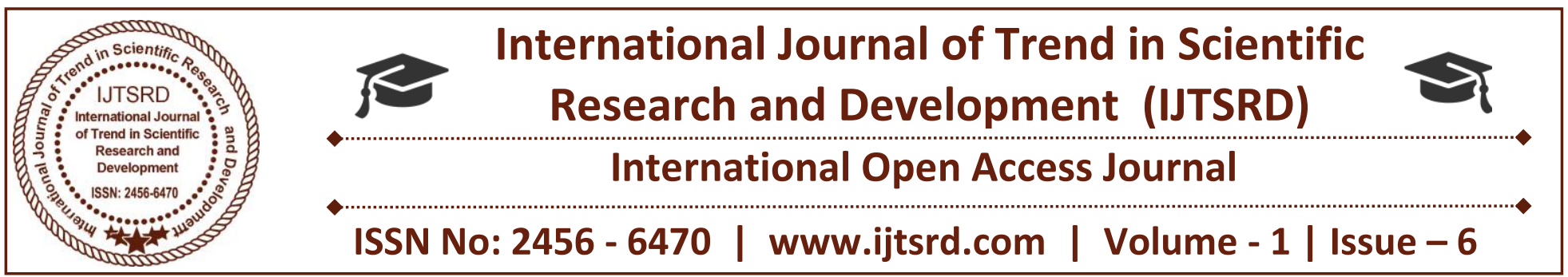

\title{
Internet Addiction among Adolescents
}

\author{
Mrs. Vandana Chauhan, \\ PhD Scholar, Himalayan \\ University, Itanagar, \\ Arunachal Pradesh, India
}

\author{
Dr. Balvinder Kaur Buttar \\ NRI College of Nursing, Amritsar, \\ Punjab, India
}

\author{
Mrs. Ramesh Singh \\ Principal, Mai Bhago College of \\ Nursing, Taran Taran, Punjab, \\ India
}

\begin{abstract}
Today we can get lots of information through internet by just a click. The trend of using internet is common especially among young generation. The aim of the present study was to find the level of internet addiction among adolescents. A cross sectional survey design was used for 52 randomly selected adolescents from private school of Haridwar, Uttarakhand. Data was collected through Kimberly Young's internet addiction scale. Result showed that more than half participants were using facebook $(71 \%)$ and whatsapp (71\%) for the purposes of chatting $92 \%$, regarding internet addiction more than half $(53.8 \%)$ of the participants had moderate internet addiction and $7.7 \%$ had severe internet addiction which could possibly affect the physical and mental health of the youngsters.
\end{abstract}

\section{Keywords: Internet, adolescents, internet addiction}

\section{Introduction}

Internet has become an essential part of our life. Through internet and Social Networking Sites (SNS), one can easily share thoughts, experiences with other person or can contact someone who is just a click away. Social networking sites has become an easy way to communicate and made possible to chat with friends who live far away. ${ }^{\mathrm{i}}$

Now a days young generation is totally depends upon social networking sites, most common sites used by them are Google, You tube, Yahoo, Gmail, Facebook,
Whatsap, Messanger, Hike, Twitter etc. ${ }^{i i}$ Youngsters almost depends on SNS, which helps them to be in touch with family and friends. Report of Internet and mobile association of India (IAMAI) and Indian Market Research Bureau (IMRB) indicates that due to affordable mobile services in India there are around 420 million mobile internet connections recorded by June 2017. ${ }^{\text {iii }}$

With these many internet connections, India has become a third largest internet user in the world and the most common users are youngsters. ${ }^{\text {iv }}$ Internet services are easily available at home, schools, colleges, libraries and cafes. Today life can not been imagined without internet. There is no doubt that the use of internet helps students in their study and updates their knowledge by providing recent information. It is also a good medium of communication and social interaction but only if it is used with cautions. Excess use of internet can cause internet addiction which may be responsible for physical and mental disturbances. ${ }^{\mathrm{v}}$

Researches shows that younger population is a high risk group for internet addiction ${ }^{\mathrm{vi}}$, reasons might be lack of supervision and guidance during the use of internet. ${ }^{\text {vii }}$ Internet addiction may refer as inability to control the desire of using internet, it can be characterized by preoccupation with internet, excessive use of internet, feeling of restlessness and depression when offline, lies to family members, poor academic performance by students and poor dietary 
habits etc. ${ }^{\text {viii }}$ Research study shows that $44.8 \%$ school going children are average users where as $14.6 \%$ were internet addicted. ${ }^{\text {ix }}$

Present study focused on to find the purposes of internet usage and level of internet addiction among adolescent students.

\section{Methodology}

Research design used for the study was cross sectional. The study was conducted in private school of Haridwar, Uttarakhand. 52 students of $11^{\text {th }}$ class were selected by simple random technique who fulfilled the selection criteria. Data was collected through administering the tool to the participants after proper explanation. Standard tool was used for data collection (internet addiction test by Kimberly Young). It consists of 20 items (5 point likert scale) that measures mild, moderate and severe level of internet addiction. Minimum score is 20 and maximum score is 100 , the scale shows that higher the score, higher the level of internet addiction. The score below 20 indicate normal user, score of 20-49 suggests mild level of internet addiction, 50-79 suggest moderate level of internet addiction and with these scores user may face occasional problems due to internet usages and score of 80-100 represent severe internet addiction in this user faces significant physical and mental problem. After collecting data it was analyzed according to the objective of the study.

\section{Result findings}

\section{Sample characteristics}

Half of the participants $51 \%$ were at the age of 16 years and $60 \%$ were female. Almost one third participants $72 \%$ living in urban area, more than half of the participant's mothers $73 \%$ and fathers $64 \%$ were graduated and above. More than one third participant's mothers 79\% were working and less than half $38 \%$ fathers had private job and business. Around one third $73 \%$ participants belong to joint family.

\section{Purposes of using internet}

The following bar diagram shows that $92 \%$ participants were using internet for chatting with their friends and family through various apps, $77 \%$ were using internet for downloading and listening song, watching videos and movies. $70 \%$ were using internet for searching study material for preparing assignments, additional information regarding study subjects etc, $42 \%$ using for online shopping, $40 \%$ using for playing online games. 37\% using for posting pictures and images on different social sites, $19 \%$ using for sending and checking e-mails, $13 \%$ using for academics quiz and survey and $4 \%$ using internet for other purposes such as to edit photo, news, daily TV shows, live telecast of matches etc.

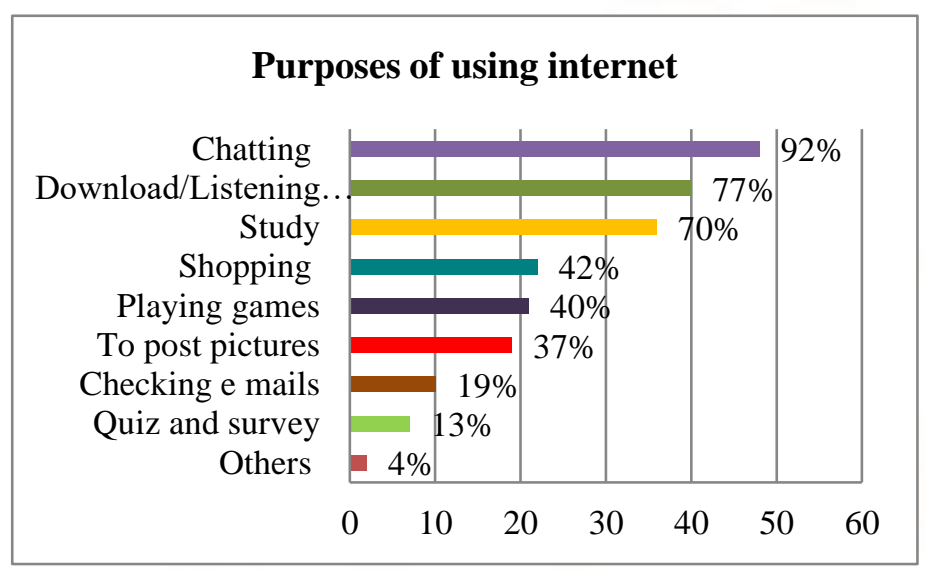

Bar diagram no 1: shows purposes of using
internet

\section{Levels of internet addiction}

Table 1: Frequency and percentage of internet uses

$\mathbf{N}=52$

\begin{tabular}{|l|l|l|}
\hline Level of addiction & Frequency & Percentage \\
\hline Normal user & 04 & 07.7 \\
\hline Mild addiction & 16 & 30.8 \\
\hline Moderate addiction & 28 & 53.8 \\
\hline Severe addiction & 04 & 07.7 \\
\hline Total & $\mathbf{5 2}$ & $\mathbf{1 0 0}$ \\
\hline
\end{tabular}

Table 1 describes the frequency and percentage of level of internet addiction among adolescents. Result shows that $7.7 \%$ participants were normal users (score 0-20) of internet, $30.8 \%$ had mild addiction, average on line users of internet and they have control over their usage, $53.8 \%$ had moderate addiction may experiencing occasional physical and mental problems and $7.7 \%$ had severe internet addiction and users might faces significant problems due to internet usage. 
International Journal of Trend in Scientific Research and Development (IJTSRD) ISSN: 2456-6470

Table 2: Gender difference in internet uses

\begin{tabular}{|l|l|l|}
\multicolumn{2}{l}{} & $\mathbf{N = 5 2}$ \\
\hline Level of addiction & Male $(\%)$ & $\begin{array}{l}\text { Female } \\
(\%)\end{array}$ \\
\hline Normal user & 9 & 6.6 \\
\hline Mild addiction & 18.2 & 40 \\
\hline $\begin{array}{l}\text { Moderate } \\
\text { addiction }\end{array}$ & 68.2 & 43.4 \\
\hline Severe addiction & 4.6 & 10 \\
\hline Total & $\mathbf{1 0 0}$ & $\mathbf{1 0 0}$ \\
\hline
\end{tabular}

Table no. 2 depicts percentage distribution of level of internet addiction with the gender of participants. Result shows that $6.6 \%$ females and $9 \%$ males were normal internet users, $40 \%$ females and $18.2 \%$ males were mildly addicted to internet where as $43.4 \%$ females and $68.2 \%$ males were moderately addicted and $10 \%$ females and $4.6 \%$ males were addicted to internet.

\section{Table no 3: Residential area and internet addiction}

\begin{tabular}{|l|l|l|l|}
\hline Level of addiction & $\begin{array}{l}\text { Urban } \\
(\%)\end{array}$ & $\begin{array}{l}\text { Rural } \\
(\%)\end{array}$ & $\begin{array}{l}\text { Semi- } \\
\text { urban } \\
\%\end{array}$ \\
\hline Normal user & 8 & 00 & 14 \\
\hline Mild addiction & 27 & 50 & 28 \\
\hline $\begin{array}{l}\text { Moderate } \\
\text { addiction }\end{array}$ & 57 & 38 & 58 \\
\hline Severe addiction & 8 & 12 & 00 \\
\hline
\end{tabular}

Table no 3 shows percentage distribution of level of internet addiction with residential area of participants. Result shows that $8 \%$ from urban and $14 \%$ from semiurban area uses internet in normal limit, half of the participants $50 \%$ from rural and approximately one forth participants from urban $28 \%$ and semi-urban area $27 \%$ had mild internet addiction where as more than half participants from urban and $38 \%$ from semiurban and rural area were moderately addicted to internet. Regarding severe addiction to internet only $8 \%$ from urban and $12 \%$ participants from rural area were severely addicted.
Different Apps used for social networking

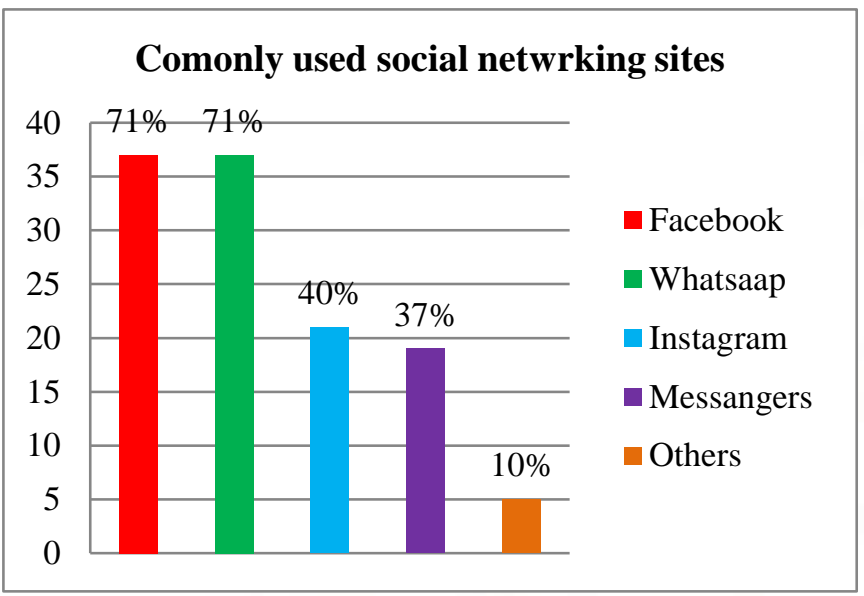

Bar diagram 2: shows use of different social networking sites

Bar diagram no 2 shows common social networking sited/aaps used by participants. Result shows that commonly used or popular social sites are (71\%) facebook and whatsaap. Other social sites less commonly used among the participants such as instagram $(40 \%)$, messenger $(37 \%)$ and other $10 \%$ (google, hike etc).

\section{Views of participants regarding internet}

Participants were asked to give their views regarding internet. Only $15.3 \%$ said that they shares their emotions and thought on social networking sites, $34.6 \%$ participants has more friends on social sites than the reality, more than half $59.6 \%$ said that usage of internet affect their studies and $82.6 \%$ said that internet is a good source for learning.

\section{Discussion}

There is no doubt that internet has been a good source of communication and learning if used cautiously otherwise it can cause physical and mental disorders among users which is known as internet addiction.

The courage of using social networking sites recently has been increased among adolescents. The most popular sites are facebook and whataap. A study done by McAfees's Tweens and Technology reports that $70 \%$ youths of India spend around 5-6 hours/week on internet. Common sites used by them are facebook $(93 \%)$, you tube (87\%) and whatsaap (79\%). On these social sites they share their private information knowingly or unknowingly, which can be dangerous for their life. Mostly they spend their time on internet for chatting and playing games online (52\%). 
Participants said that they feel more comfortable on social sites, $72 \%$ feel important when they receive like on their post. ${ }^{\mathrm{x}}$

In present study more than half $53.8 \%$ of the participants had moderate internet addiction and $7.7 \%$ had severe internet addiction. Study conducted by Goel D, Subramanyam A and Kamath R showed that $74.5 \%$ participants were moderate addicted and $0.7 \%$ participants were severely addicted to internet.

\section{CONCLUSION}

Form the finding of the study it can be concluded that most of the participants uses internet for chatting, downloading and listening music/video and for study. Most common sites used by them are facebook and whatsaap. Result shows that more than half of the participants were above average users of internet. It should be the responsibility of parents to control the use of internet by guiding their children to prevent complication of internet such as misuse of internet and internet addiction, which affect physical and mental health of individual.

\section{REFERENCES}

1. Rheingold $H$. The vytual community: homesteading on the electronic frontier. MTI: C

2. Effect of social networking sites on today's youth, http://roundthebendthoughts.wordpress.com/2012/ 10/20/effects-of-social-networking-sites-ontodays-youth/

3. The economic times: internet users to touch 420 million by June 2017: IAMAI report by Surabhi Agarwal, ET Bureau, May 2017 http://economictimes.indiatimes.com/tech/internet/420 -million-to-access-internet-on-mobile-in-india-byjune-iamai/articleshow/58475622.cms)

4. Special correspondent The hindu: 2013 http://www.thehindu.com/scitech/technology/internet/india-is-now-worlds-thirdlargest-internet-user-after-us-china/article5053115.ece

5. A study on the prevalence of internet addiction and its association with psychopathology in Indian adolescents Deepak Goel, Alka Subramanyam, and Ravindra Kamath, Indian J Psychiatry. 2013 Apr-Jun; 55(2): 140-143. doi: 10.4103/0019-5545.111451,
PMCID: PMC3696236

https://www.ncbi.nlm.nih.gov/pmc/articles/PMC3 696236/

6. Daniel T, Shek L, Rachel C, Sun F, Lu YU. Neuroscience in the $21{ }^{\text {st }}$ Century from Basic to Clinical. $\quad 2^{\text {nd }}$ ed. New York: Springer Science+Business Media LLC; 2013

7. Kandell JJ. Internet addiction on campus: The vulnerability of college students. Cyberpsychol Behav. 1998;1:11-7.

8. Unity point health, illionis institute for addiction recovery: http://www.addictionrecov.org/Addictions/index.aspx? $\mathrm{AID}=43$

9. Janki Jhala, Renu Sharma, Prevalence and Nature of Internet Use among Adolescents in Vadodara (Gujarat), The International Journal of Indian Psychology ISSN 2348-5396 (e) | ISSN: 2349-3429 (p) Volume 4, Issue 2, No. 95, DIP: 18.01.164/20170402 ISBN: 978-1-365-84231-3 http://www.ijip.in January-March, 2017

10. Young KS. Internet Addiction: The emergence of a new clinical disorder.Cyberpsychol Behav 1998;3:237-44.

11. Indiafact, internet and social media usage among youth in India: Mcafee Report http://indiafacts.in/report/internet-social-mediausage-among-youth-india-mcafee-report/ 